OPEN ACCESS

Edited by:

Luca Persani,

University of Milan, Italy

Reviewed by:

Roberto Lanes,

Hospital de Clinicas Caracas,

Venezuela

Hugo Fideleff,

University of Buenos Aires, Argentina

${ }^{*}$ Correspondence:

Matteo Spaziani

matteo.spaziani@uniroma1.it

Specialty section:

This article was submitted to

Pituitary Endocrinology,

a section of the journal

Frontiers in Endocrinology

Received: 27 November 2020

Accepted: 11 January 2021

Published: 24 February 2021

Citation:

Spaziani M, Tarantino C, Tahani N. Gianfrilli $D$, Sbardella E, Isidori AM,

Lenzi A and Radicioni AF (2021) Clinical, Diagnostic, and Therapeutic

Aspects of Growth Hormone

Deficiency During the Transition

Period: Review of the Literature.

Front. Endocrinol. 12:634288.

doi: 10.3389/fendo.2021.634288

\section{Clinical, Diagnostic, and Therapeutic Aspects of Growth Hormone Deficiency During the Transition Period: Review of the Literature}

\author{
Matteo Spaziani ${ }^{1,2 *}$, Chiara Tarantino ${ }^{1,2}$, Natascia Tahani ${ }^{3}$, Daniele Gianfrilli ${ }^{1}$, \\ Emilia Sbardella ${ }^{1}$, Andrea M. Isidori ${ }^{1}$, Andrea Lenzi ${ }^{1}$ and Antonio F. Radicioni ${ }^{1,2}$ \\ 1 Section of Medical Pathophysiology and Endocrinology, Department of Experimental Medicine, Sapienza University \\ of Rome, Rome, Italy, ${ }^{2}$ Centre for Rare Diseases, Policlinico Umberto I, Rome, Italy, ${ }^{3}$ Department of Diabetes, \\ Endocrinology and Metabolism, Queen Elizabeth Hospital, University Hospitals Birmingham NHS Foundation Trust, \\ Birmingham, United Kingdom
}

The role of growth hormone $(\mathrm{GH})$ during childhood and adulthood is well established. Once final stature is reached, $\mathrm{GH}$ continues to act during the transition, the period between adolescence and adulthood in which most somatic and psychological development is obtained. The achievement of peak bone mass represents the most relevant aspect of $\mathrm{GH}$ action during the transition period; however, equally clear is its influence on body composition and metabolic profile and, probably, in the achievement of a complete gonadal and sexual maturation. Despite this, there are still some aspects that often make clinical practice difficult and uncertain, in particular in evaluating a possible persistence of $\mathrm{GH}$ deficiency once final stature has been reached. It is also essential to identify which subjects should undergo re-testing and, possibly, replacement therapy, and the definition of unambiguous criteria for therapeutic success. Moreover, even during the transition phase, the relationship between GH substitution therapy and cancer survival is of considerable interest. In view of the above, the aim of this paper is to clarify these relevant issues through a detailed analysis of the literature, with particular attention to the clinical, diagnostic and therapeutic aspects.

Keywords: transition period, bone, body composition, metabolism, gonad function, growth hormone deficiency, cancer survivors

\section{INTRODUCTION}

The importance and effectiveness of somatotropic hormone replacement therapy (rh-GH) in children with low stature and/or linear growth decline associated with growth hormone deficiency (GHD) is well established. In childhood, there is a diagnostic procedural standard and therapeutic success can be easily evaluated based on the increase in the linear growth rate and the repositioning in the family height target. Nevertheless, there are not the same certainties during the transition period, both in diagnostic and therapeutic terms, even though it has been widely debated in the last 2 decades (1). 
The transition phase begins with the achievement of final height and ends with the achievement of peak bone mass. The mean age of the transition onset differs according to sex and the achievement of Prader's pubertal stage 5 or final adult height. According to Prader, in pubertal stage 5, the mean age is $14.7 \pm$ 2.2 years in boys and $14.0 \pm 2.4$ years in girls; when considering the final height, the mean age is $16.8 \pm 2.2$ years in boys and 15.2 \pm 2.0 years in girls, and in both cases with a growth velocity $<1.5-$ $2 \mathrm{~cm} /$ year (2). The end of the transition period usually corresponds with peak bone mass, which occurs at an average age of 23.1 years in males and 19.9 years in females (3). Other Authors define the end of the transition by referring to the sleep chronotype, A percentage of between 25 and $100 \%$ of subjects, which occurs at a mean age of 20.9 years for males or 19.5 years for females (4).

The aim of this review is to address the main questions and doubts related to transition, focusing on the diagnostic, clinical and therapeutic tools.

\section{GHD DIAGNOSIS IN TRANSITION: THE IMPORTANCE OF RE-TESTING}

A percentage of between $25 \%$ and $100 \%$ of subjects with previous childhood-onset GHD (CO-GHD) display a normalization of $\mathrm{GH}$ secretion when undergoing re-testing (5).

It is usually recommended 1-3 months between the end of the childhood rh-GH and the time of re-testing (6). This period should not exceed 6 months $(5,7)$. Of note, not all subjects need to be re-tested: patients with more than two pituitary hormone deficits; isolated GHD associated with an identified mutation and or a specific pituitary/hypothalamic structural defect, except for an ectopic posterior pituitary; the presence of a transcriptionfactor mutation $(6,8)$. The positive predictive value for GHD in adulthood is $96 \%$ in the presence of three or more pituitary hormone deficiencies and even $99 \%$ in the case of four hormone deficits (9). Re-testing should be carried out in the following cases: idiopathic isolated GHD with or without a small pituitary/ ectopic posterior pituitary; GHD associated with only one other pituitary hormone deficiency; patients previously treated with radiation therapy.

Table 1 provides a systematic list of the different available provocative tests, with their respective cut-off values. The gold standard is the Insulin Tolerance Test (ITT) (10-12). In the case of contraindications, such as seizures or confirmed cerebrovascular and cardiovascular risk factors, an alternative is the Glucagon test $(10,14)$. Another tool used for the diagnosis of GHD is the Arginine test, but it has been shown not to be very effective (11). Finally, the GHRH+Arginine test is not recommended in case of idiopathic GHD, because it may result in a false-positive response $(8,10)$. In addition, a 2005 study showed that this test should not be used for the diagnosis of GHD in those adults treated with cranial irradiation (CRT) for childhood acute lymphoblastic leukemia, as it could result in a false-positive response (15). For this test, the Italian Medical Agency set the cut-off value to $19 \mu \mathrm{g} / \mathrm{L}$ (16). A recent study
TABLE 1 | List of the different available GH provocative tests, whit their respective cut-off values.

\begin{tabular}{|c|c|c|c|}
\hline Test & BMI & Cut-off & References \\
\hline \multirow{4}{*}{$\begin{array}{l}\mathrm{GHRH}+ \\
\text { Arginine test }\end{array}$} & $\mathrm{BMl}<25 \mathrm{~kg} / \mathrm{m} 2$ & $<11 \mu \mathrm{g} / \mathrm{L}$ & $(8,10)$ \\
\hline & BMl 25-30 kg/m2 & $<8 \mu \mathrm{g} / \mathrm{L}$ & $(8,10)$ \\
\hline & $\mathrm{BMl}>30 \mathrm{~kg} / \mathrm{m} 2$ & $<4 \mu \mathrm{g} / \mathrm{L}$ & $(8,10)$ \\
\hline & & $<19 \mu \mathrm{g} / \mathrm{L}$ & (11) \\
\hline \multirow{4}{*}{$\begin{array}{l}\text { Insulin } \\
\text { Tolerance Test } \\
\text { (ITT) }\end{array}$} & & $<5 \mu \mathrm{g} / \mathrm{L}$ & $(10)$ \\
\hline & & & \\
\hline & & $<6,1 \mu \mathrm{g} / \mathrm{L}$ & $(12)$ \\
\hline & & $<5,6 \mu \mathrm{g} / \mathrm{L}$ & (13) \\
\hline \multirow[t]{4}{*}{ Glucagon test } & $\mathrm{BMl}<25 \mathrm{~kg}$ & $<3 \mu \mathrm{g} / \mathrm{L}$ & $(10,14)$ \\
\hline & $\begin{array}{l}\text { BMl } 25-30 \mathrm{~kg} / \mathrm{m} 2 \\
\text { (high pretest } \\
\text { probability) }\end{array}$ & $<3 \mu \mathrm{g} / \mathrm{L}$ & $(10,14)$ \\
\hline & $\begin{array}{l}\text { BMl } 25-30 \mathrm{~kg} / \mathrm{m} 2 \text { (low } \\
\text { pretest probability) }\end{array}$ & $<1 \mu \mathrm{g} / \mathrm{L}$ & $(10,14)$ \\
\hline & $\mathrm{BMl}>30 \mathrm{~kg} / \mathrm{m} 2$ & $<1 \mu \mathrm{g} / \mathrm{L}$ & $(10,14)$ \\
\hline Arginine test & & $<0.4 \mu \mathrm{g} / \mathrm{L}$ & (11) \\
\hline
\end{tabular}

investigated the diagnostic accuracy of the GHRH+Arginine test concluding that it should provide specific cut-off points depending on the pathological condition, such as congenital GHD, isolated GHD, multiple pituitary hormone defects and cancer survivors (17).

The possibility of anticipating the time of re-testing, to avoid a hypothetical over-treatment, has been recently investigated by Penta and colleagues (18). The Authors claimed that it would be useful to re-test patients with idiopathic and isolated GHD before reaching final stature or Tanner stage 5, in order to avoid over-treatment.

A special mention should be made of IGF-1: a normal or high IGF1 value alone cannot rule out the diagnosis of GHD (19), as well as a low value alone is not sufficient to make the diagnosis $(17,20)$. Moreover, to date the chemiluminescence immunoassay should be the preferred method as it is considered the most appropriate and accurate (21).

\section{THE ROLE OF GH DURING TRANSITION: EFFECTS ON BONE, BODY COMPOSITION, METABOLISM, AND GONADAL FUNCTION}

There are numerous studies on the effect and importance of GH during the transition phase. Most of them focus on the influence on bone, metabolism and body composition. In this section, we will also mention the impact of GH on fertility.

\section{Bone}

$\mathrm{GH}$ and its mediator IGF-1 have a cumulative effect of raising bone turnover and mass, leading to an increase in endochondral ossification and linear growth.

Although most studies in the literature agree on the role of $\mathrm{GH}$ in improving bone quality, there is no unequivocal opinion 
in this regard. Starting with Randomized Controlled Studies (RCTs), Carroll and Drake respectively showed an increase in total body BMC (TB-BMC) of about $6 \%$ and lumbar spine BMC (LS-BMC) of about $5 \%$ in treated subjects compared to untreated $(22,23)$. In a 2 -year RCT, an increase of $5 \%$ in the total bodybone mineral density (TB-BMD) was found in subjects treated with rh-GH, compared to $1.3 \%$ of untreated patients (24). In another 2-year RCT, subjects were randomized either to an adult dose of rh-GH or to a paediatric dose or to a placebo, with an increase of TB-BMD, respectively of 3.3\%, 5\%, and $1.3 \%$ (25). By contrast, another multicentre RCT study, in which $18 \mathrm{GHD}$ subjects were randomized to rh-GH and 15 to placebo, no substantial increase in BMD between the two groups was demonstrated (26). The same findings were obtained by Boot and Hyldstrup $(27,28)$.

A 2014 cross-sectional study compared 18 subjects with previous CO-GHD diagnosis, who were further subdivided into two sub-groups of nine patients, each based on the persistence or not of GHD after re-testing, with 18 healthy subjects. They showed a reduction in TB-BMD and LS-BMD both in GHD and in non-GHD subjects compared to controls, demonstrating that the previous administration of rh-GH was not sufficient to determine a normal BMD (29).

Of note, CO-GHD patients tend to have smaller bones than control subjects; this may lead to underestimation of Areal BMD assessed by dual energy X-ray absorptiometry (DXA) scan (30, 31) and contribute to discrepancies in the interpretation of results among different investigations. Therefore, it should be considered that those patients with CO-GHD, not treated with rh-GH during childhood, have a significant reduction of the Areal BMD, but a normal Volumetric BMD.

Some studies also assessed the impact of GH on the microarchitectural characteristics of bone. A significant increase in both BMD and in cortical thickness in subjects undergoing rh$\mathrm{GH}$ has been found by Hyldstrup et al (28)., whereas another study found a significant reduction in cortical bone area and thickness in untreated CO-GHD adults compared with AOGHD (32). Of note, there are no studies that unequivocally demonstrate an increased risk of fractures in GHD subjects during the transition $(33,34)$.

It should be noted that changes related to eating habits, physical activity and socioeconomic status of patients might occur during rh-GH and they can influence the outcome of bone, metabolic, cardiac and body composition parameters. This makes it more difficult to understand the weight of rh-GH alone in all these changes. Moreover, other pituitary deficiencies and their treatments could play a role in bone metabolism, as the prevalence of fractures is markedly increased in patients with multiple pituitary deficiencies (35).

\section{Body Composition}

Some studies highlighted that a long period off rh-GH induces a consistent increase in the percentage of fat mass (FM) and trunk fat, with a decrease in lean mass (LM) (36-38). During the transition phase, several papers argued that in patients with a GHD persistence and that do not resume rh-GH, there was a reduction in LM and an increase in FM compared to control subjects or those who resumed rh-GH. The LM decreased by about $8 \%$, compared to an average increase of about $15 \%$ in FM $(22,39,40)$. The resumption of $\mathrm{rh}-\mathrm{GH}$, showed a clear improvement, with an increase in LM of about $14 \%$ and a decrease in FM of about $7 \%$ after 2 years of therapy $(24,41)$. In contrast, Mauras et al. found no improvement in body composition after 2 years of treatment (26).

Another paper investigated early body composition changes after the rh-GH break in a population with persistent GHD, finding a significant increase in FM especially in those with multiple pituitary deficits, and a significant reduction in crosssectional muscle area Z-score (42).

$\mathrm{GH}$ exerts considerable effects on skeletal muscle, inducing a global effect of muscle growth through the stimulation of freefatty acids and amino-acid uptake, and the increase of protein synthesis. Rh-GH should not be used during the transition with the only aim of muscle growth, even though several studies have shown clear lower muscle strength in confirmed GHD subjects compared to sufficient or healthy controls (43). A recent study assessed how 12 weeks of resistance exercise alone could improve muscle strength during the transition (44). Interesting is the interconnection between GH, leptin and ghrelin. Leptin, that reduces the sense of appetite, is primarily secreted by white adipose tissue, and its concentration correlates positively with total FM. Ghrelin has an opposite effect and is mainly secreted by $\mathrm{P} / \mathrm{D} 1$ cells lining the fundus of the stomach and epsilon cells in the pancreas. Ghrelin represents a powerful stimulator to $\mathrm{GH}$ secretion, as it is a natural ligand for the GH-secretagogue receptor (45). In a study by Roemmler and colleagues, it was shown that rh-GH was able to reduce the total FM and consequently the leptin levels, albeit there was a no significant increase of ghrelin (46). This connection between GH, ghrelin and leptin paves the way for the possible role of $\mathrm{GH}$ in appetite regulation (47).

\section{Metabolic Aspects and Cardiovascular Risk}

Many studies report a worsening of the lipid pattern after discontinuation of the rh-GH $(41,42,48)$, although others do not show any substantial difference between patients who resume therapy and subjects who do not $(22,24,26)$.

As a general statement we can say that the later treatment begins in childhood and the longer the period off rh-GH lasts during the transition, the worse the lipid profile becomes, with higher total cholesterol and triglyceride levels (49), suggesting that discontinuation of rh-GH during the transition is associated with a pro-atherogenic lipid profile.

Some studies also demonstrated the influence of GH on postprandial lipid values. Lanes and co-Authors, in 2004, showed an increase in post-prandial triglyceride values ( $4 \mathrm{~h}$ after a high-fat meal) and peripheral inflammatory and fibrinolytic markers in 
untreated compared to treated subjects (50). In addition, higher levels of basal triglycerides and overlapping values of postprandial triglycerides compared to an age-matched control group have been found in a population of GHD subjects. This metabolic situation remained unchanged after 4 months of rhGH (51).

Regarding the effects on glucose metabolism, there are no unequivocal results. While some papers reported an improvement in insulin sensitivity following therapy discontinuation after reaching final stature (52), other studies came to opposite conclusions. One study, in particular, reported a significant increase in insulin resistance following a period of 6 months off rh-GH, which tended to disappear 6 months after the resumption of therapy (53). Some papers highlighted a possible gender-specific difference in carbohydrate metabolism and body composition. Specifically, in a 2004 metanalysis, it is reported that males are more sensitive to the effect of rh-GH on insulin sensitivity (54). Regarding body composition, women seem to be less sensitive than men, and require higher rh-GH doses to achieve the same benefits (55).

There is currently insufficient data to determine whether rh$\mathrm{GH}$ may induce an increased risk of type 2 diabetes mellitus in the future.

The effects of rh-GH on the heart were evaluated in an echocardiographic study, which compared 21 previously treated patients with 21 age- and sex-matched healthy controls. The Authors found that in the 21 studied patients both the heart height and size were lower than in the controls, despite longterm rh-GH during childhood. Then, eight of the 21 patients were subjected again to rh-GH for 15 months during the transition period and they showed a significant increase in left ventricular mass and an improvement in endothelial function within the first 6 months of restarting rh-GH (56). Finally, a 2003 study reported an increase of intima-media thickness (IMT) in subjects with previous CO-GHD, compared to both adult-onset GHD patients and to controls (57); however, this finding was not confirmed in two further studies $(53,58)$.. An interesting study, carried out in $20 \mathrm{GH}$-naive Brazilian adults, due to a homozygous mutation in GHRH receptor gene, demonstrated a significant improvement in their lipid metabolic profile after 6 months of rh-GH, while a progressive increase in the number of atherosclerotic carotid plaques was still noted. Moreover, a relevant increase in both cardiac structural parameters (left ventricular mass index, posterior wall, and septum thickness) and carotid IMT was found after 6-12 months of rh-GH suspension (59).

In relation to vascular reactivity, a study conducted in 10 GHD-treated adolescents, 12 GHD untreated adolescents and 14 controls, noted a lower flow-mediated endothelium-dependent increase in the diameter of the brachial artery during hyperemia in untreated subjects. In addition, the hyperemia-induced blood flow increase was higher in treated patients than in controls and in untreated GHD adolescents. The presence of such vascular abnormalities, together with the increased epicardial adipose tissue thickness, lead to an increased cardiovascular risk in non-treated subjects, even though it is reversible after rh-GH (60). Abnormal vascular reactivity in young GHD adults was also confirmed in a previous study, which demonstrated a reduction of the brachial artery vasodilation induced by specific vasodilators (acetylcholine and sodium nitroprusside) in seven childhood-onset GHD patients. However, these vascular abnormalities were not confirmed in subjects with CO-GHD who had received adequate $\mathrm{rh}-\mathrm{GH}$, confirming that GHD was a trigger (61).

Finally, rh-GH can also influence blood pressure. Most of the studies argue that rh-GH induces a reduction in diastolic blood pressure and no change in systolic blood pressure, through an increase in nitric oxide formation, stimulation of the reninaldosterone system and decrease in intima-media thickness (62). To date, there is only a study in which rh-GH was clearly associated with hypertension (63).

\section{GH and Gonadal Function}

The effect of rh-GH on gonadal function has been widely investigated, since it influences the hypothalamic-pituitarygonadal axis, facilitating the release of $\mathrm{GnRH}$ and consequently of gonadotropins (64).

In 1994 our group described the effect of the rh-GH on the improvement of spermatogenesis in 10 infertile patients presenting with idiopathic severe oligozoospermia, normogonadotropinemia, or moderate hypergonadotropinemia, with low IGF-1 values or values within the lower limit of the normal range. Short-term rh$\mathrm{GH}$ led to an improvement in both sperm concentration and motility in $50 \%$ of subjects (65). In a subsequent paper, we ruled out the possibility of prolonged rh-GH use negatively affecting testicular development or function (66).

In women, IGF-1 plays a role in the proliferation and differentiation of granulosa cells and stimulates steroidogenesis in large follicles and theca cells. Furthermore, a recent study showed that GH, along with IGF-1, interacts with local ovarian factors, such as VEGF-A and FGF-2, thus being a necessary actor in the ovarian angiogenesis (67).

\section{IMPACT ON QUALITY OF LIFE}

The impact of rh-GH on the quality of life (QoL) of GHD patients during the transition period seems less clear than in adulthood.

However, Abs and co-authors showed a positive relationship between stature gain after rh-GH in childhood and the improved QoL during the transition, while a negative relationship between the duration of rh-GH discontinuation and QoL was reported (34). Another paper evaluated through a survey the impact of rh$\mathrm{GH}$ on QoL at baseline and after 1 and 2 years of rh-GH, finding that body shape and sexual arousal were significantly lower after rh-GH suspension, thus negatively affecting the QoL (68). In contrast to Mauras' paper (26), several studies agreed that rh-GH is effective in improving QoL, with a significant positive change in health-related aspects $(68,69)$. 
Finally, the effect of therapy resumption was studied in another couple of studies, which showed a worsening of the QoL after 1 year of rh-GH suspension, counterbalanced following 6 months of rh-GH resumption $(70,71)$.

\section{WHAT IS THE RIGHT THERAPEUTIC DOSAGE DURING THE TRANSITION?}

During the transition, the tendency is to start with an intermediate dose between 0.22 and $0.30 \mathrm{mg} / \mathrm{kg} /$ week as in childhood and 0.01-0.1 mg/kg/week as in adulthood (72).

In case the therapy was suspended after reaching final height, it should be resumed at a dosage of $0.21 \mathrm{mg} / \mathrm{kg} / \mathrm{week}$, and then titrate based on age, IGF-1 values, clinical response and the possible appearance of adverse effects (73). However, based on our clinical practice, we recommend starting with the lowest therapeutic dose and then adjust dosage according to IGF-1 levels, clinical response and absence (even minimal) of adverse effects. Table 2 summarises the possible main side effects associated with rh-GH.

In women receiving oral oestrogen replacement therapy, higher doses of rh-GH are typically required, as oral oestrogens seem to attenuate the metabolic actions of $\mathrm{GH}$ on its liver receptor, lowering IGF-1 secretion. It would therefore be preferable to use transdermal oestrogens, in order to avoid/ attenuate the effect on the liver (74).

Regarding the production of thyroid hormones, rh-GH can cause a slight reduction in FT4 and TSH levels, and an increase in FT3 and could therefore unmask central hypothyroidism (75). Therefore, before starting rh-GH and during treatment, thyroid function should be monitored closely, particularly in the first 6 months.

At the adrenal level, $\mathrm{GH}$ can reduce the activity of the enzyme $11 \beta \mathrm{HSD} 1$, resulting in reduced conversion of cortisone to cortisol. Thus, an assessment of the HPA axis function (through the evaluation of basal AM and PM cortisol levels and, when needed, after stimulation, e.g., ACTH test or ITT) should be made before and after starting rh-GH, as GHD could mask the presence of a hidden central hypoadrenalism (76).

Rh-GH, even during the transition, must be carefully monitored to avoid the onset of possible adverse events. Every 6 months, it is advisable to carry out a haematochemical screening, with the evaluation of IGF-1, serum glucose, HbA1c and lipid profile, and a clinical evaluation based essentially on the measurement of weight and waist circumference and blood

TABLE 2 | Main side effects associated with rh-GH.

Side effects

Headache

Glucose disorders

Insulin resistance

Idiopathic intracranial hypertension

Increased intraocular pressure

Arthralgia pressure. Every year a possible improvement in bone mineral density through a DXA scan, and of the intima media thickness by ultrasound examination should be evaluated, as well as any positive changes in QoL (12).

\section{GH TREATMENT IN CANCER SURVIVORS DURING TRANSITION}

GHD is the most frequent endocrine disorder in childhood cancer survivors, especially in those with a history of pathology (and treatments) of the hypothalamic-pituitary region (20). In this respect, there is no unequivocal data on the risk of recurrence, as several studies indicate a very low or no-risk (77-80), whereas others provide no certain conclusions (81). The same risk of recurrence in GH-treated cancer survivors compared to non-treated subjects was found in two different studies $(82,83)$.

Others found no increased risk of cancer recurrence in a rhGH treated paediatric population (84) and in patients with previous brain cancer $(85,86)$. As to the risk of developing a secondary neoplasm, a recent meta-analysis indicated that rh$\mathrm{GH}$ seems not increase this risk (87). However, opposite results were found in other relevant studies, such as CCSS, GeNeSIS, and HypoCCS, in which the percentage of second neoplasms was $3.8 \%$ in GeNeSIS and 6\% in HypoCCS $(77,88)$.

The Endocrine Society suggests starting rh-GH 1 year after stopping cancer therapy, when there is no more evidence of cancer disease. In the case of chronic or not totally eradicable oncological diseases, the choice whether to start rh-GH or not should be tailored according to the characteristics of the tumor and the patient, after a proper discussion with the oncologist (20).

A very controversial topic is the choice of the therapeutic rh$\mathrm{GH}$ dose. However, it should be appropriate to use the minimum effective dose so as to decrease symptomatology. The most widely used and free of side effects therapy is the daily administration of $0.21 \mathrm{mg} / \mathrm{kg} /$ week, adjusted so as to reach normal IGF-1 levels (89).

To summarise, papers published so far show that somatotropin is indicated in those patients who have GHD and it appears safe in terms of tumor recurrence. Of course, caution is extremely important in the follow-up of GHD patients during the transition period, but it would be inappropriate to deprive them of therapy that is central to treating this deficiency.

\section{CONCLUSIONS}

Transition is a period in life in which the maturation of the organism is completed. During the transition, GH plays a relevant role on bone maturation, metabolism and body composition. GHD increases cardiovascular risk and impacts fertility negatively. For these reasons, GH is considered extremely important for a good quality of life. There are still uncertainties about when and how to re-test to confirm or not a persistent GHD in patients previously treated with somatotropin, and there is still no total agreement regarding the therapeutic dosage. The link between rh-GH and tumor recurrence in cancer survivors is not 
totally clear. However, most of the studies report no evidence of increased recurrence risk in these patients during the transition.

Further studies with a longer duration of rh-GH are needed, in order to assess with more accuracy, the effects of rh-GH during the transition, and eliminate those uncertainties that are still present on this fascinating but often too feared hormone.

\section{REFERENCES}

1. Yuen KCJ, Biller BMK, Radovick S, Carmichael JD, Jasim S, Pantalone KM, et al. American association of clinical endocrinologists and American college of endocrinology guidelines for management of growth hormone deficiency in adults and patients transitioning from pediatric to adult care. Endocr Pract (2019) 25(11):1191-232. doi: 10.4158/GL-2019-0405

2. Prader A, Largo RH, Molinari L, Issler C. Physical growth of Swiss children from birth to 20 years of age. First Zurich longitudinal study of growth and development. Helv Paediatr Acta (1989) 52:1-125.

3. Boot AM, de Ridder MA, van der Sluis IM, van Slobbe I, Krenning EP, KeizerSchrama SM. Peak bone mineral density, lean body mass and fractures. Bone (2010) 46(2):336-41. doi: 10.1016/j.bone.2009.10.003

4. Roenneberg T, Merrow M. The circadian clock and human health. Curr Biol (2016) 26(10):R432-43. doi: 10.1016/j.cub.2016.04.011

5. Maghnie M, Strigazzi C, Tinelli C, Autelli M, Cisternino M, Loche S, et al. Growth hormone (GH) deficiency (GHD) of childhood onset: reassessment of GH status and evaluation of the predictive criteria for permanent GHD in young adults. J Clin Endocrinol Metab (1999) 84(4):1324-8. doi: 10.1016/ j.cub.2016.04.011

6. Clayton PE, Cuneo RC, Juul A, Monson JP, Shalet SM, Tauber M. European Society of Paediatric Endocrinology. Consensus statement on the management of the GH-treated adolescent in the transition to adult care. Eur J Endocrinol (2005) 152(2):165-70. doi: 10.1530/eje.1.01829

7. Radovick S, DiVall S. Approach to the growth hormone-deficient child during transition to adulthood. J Clin Endocrinol Metab (2007) 92(4):1195-200. doi: 10.1210/jc.2007-0167

8. Molitch ME, Clemmons DR, Malozowski S, Merriam GR, Vance ML. Endocrine Society. Evaluation and treatment of adult growth hormone deficiency: an Endocrine Society clinical practice guideline. J Clin Endocrinol Metab (2011) 96:1587-609. doi: 10.1210/jc.2011-0179

9. Hartman ML, Crowe BJ, Biller BM, Ho KK, Clemmons DR, Chipman JJ. HyposCCS Advisory Board; U.S. HypoCCS Study Group. Which patients do not require a GH stimulation test for the diagnosis of adult GH deficiency? $J$ Clin Endocrinol Metab (2002) 87(2):477-85. doi: 10.1210/jcem.87.2.8216

10. Cook DM, Yuen KC, Biller BM, Kemp SF, Vance ML. American Association of Clinical Endocrinologists. American Association of Clinical Endocrinologists medical guidelines for clinical practice for growth hormone use in growth hormone deficient adults and transition patients2009 update. Endocr Pract (2009) 15(Suppl 2):1-29. doi: 10.4158/EP.15.6.580

11. Aimaretti G, Attanasio R, Cannavò S, Nicoletti MC, Castello R, Di Somma C, et al. Growth hormone treatment of adolescents with growth hormone deficiency (GHD) during the transition period: results of a survey among adult and paediatric endocrinologists from Italy. Endorsed by SIEDP/ISPED, AME, SIE, SIMA. J Endocrinol Invest (2015) 38(3):377-82. doi: 10.1007/ s40618-014-0201-7

12. Secco A, di Iorgi N, Napoli F, Calandra E, Calcagno A, Ghezzi M, et al. Reassessment of the growth hormone status in young adults with childhoodonset growth hormone deficiency: reappraisal of insulin tolerance testing. $J$ Clin Endocrinol Metab (2009) 94(11):4195-204. doi: 10.1210/jc.2009-0602

13. Dichtel LE, Yuen KC, Bredella MA, Gerweck AV, Russell BM, Riccio AD, et al. Overweight/Obese adults with pituitary disorders require lower peak growth hormone cutoff values on glucagon stimulation testing to avoid overdiagnosis of growth hormone deficiency. J Clin Endocrinol Metab (2014) 99(12):4712-9. doi: 10.1210/jc.2014-2830

14. Loche S, Di Iorgi N, Patti G, Noli S, Giaccardi M, Olivieri I, et al. Growth Hormone Deficiency in the Transition Age. Endocr Dev (2018) 33:46-56. doi: $10.1159 / 000487525$

\section{AUTHOR CONTRIBUTIONS}

All the authors have made a substantial, direct and intellectual contribution to the work. MS revised it critically. All authors approved the work for publication. All authors contributed to the article and approved the submitted version.

15. Björk J, Link K, Erfurth EM. The utility of the growth hormone (GH) releasing hormone-arginine test for diagnosing GH deficiency in adults with childhood acute lymphoblastic leukemia treated with cranial irradiation. J Clin Endocrinol Metab (2005) 90(11):6048-54. doi: 10.1210/jc.2005-0304

16. Corneli G, Di Somma C, Prodam F, Bellone J, Bellone S, Gasco V, et al. Cut-off limits of the GH response to GHRH plus arginine test and IGF-I levels for the diagnosis of GH deficiency in late adolescents and young adults. Eur J Endocrinol (2007) 157(6):701-8. doi: 10.1530/EJE-07-0384

17. Patti G, Noli S, Capalbo D, Allegri AME, Napoli F, Cappa M, et al. Accuracy and Limitations of the Growth Hormone (GH) Releasing Hormone-Arginine Retesting in Young Adults With Childhood-Onset GH Deficiency. Front Endocrinol (Lausanne) (2019) 10:525:525. doi: 10.3389/fendo.2019.00525

18. Penta L, Cofini M, Lucchetti L, Zenzeri L, Leonardi A, Lanciotti L, et al. Growth Hormone (GH) Therapy During the Transition Period: Should We Think About Early Retesting in Patients with Idiopathic and Isolated GH Deficiency? Int J Environ Res Public Health (2019) 16(3):307. doi: 10.3390/ ijerph 16030307

19. Appelman-Dijkstra NM, Kokshoorn NE, Dekkers OM, Neelis KJ, Biermasz NR, Romijn JA, et al. Pituitary dysfunction in adult patients after cranial radiotherapy: systematic review and meta-analysis. J Clin Endocrinol Metab (2011) 96(8):2330-40. doi: 10.1210/jc.2011-0306

20. Sklar CA, Antal Z, Chemaitilly W, Cohen LE, Follin C, Meacham LR, et al. Hypothalamic-Pituitary and Growth Disorders in Survivors of Childhood Cancer: An Endocrine Society Clinical Practice Guideline. J Clin Endocrinol Metab (2018) 103(8):2761-84. doi: 10.1210/jc.2018-01175

21. Ho KKGH Deficiency Consensus Workshop Participants. Consensus guidelines for the diagnosis and treatment of adults with GH deficiency II: a statement of the GH Research Society in association with the European Society for Pediatric Endocrinology, Lawson Wilkins Society, European Society of Endocrinology, Japan Endocrine Society, and Endocrine Society of Australia. Eur J Endocrinol (2007) 157(6):695-700. doi: 10.1530/EJE-070631

22. Carroll PV, Drake WM, Maher KT, Metcalfe K, Shaw NJ, Dunger DB, et al. Comparison of continuation or cessation of growth hormone (GH) therapy on body composition and metabolic status in adolescents with severe GH deficiency at completion of linear growth. J Clin Endocrinol Metab (2004) 89 (8):3890-5. doi: 10.1210/jc.2003-031588

23. Drake WM, Carroll PV, Maher KT, Metcalfe KA, Camacho-Hübner C, Shaw $\mathrm{NJ}$, et al. The effect of cessation of growth hormone (GH) therapy on bone mineral accretion in GH-deficient adolescents at the completion of linear growth. J Clin Endocrinol Metab (2003) 88(4):1658-63. doi: 10.1210/jc.2002021541

24. Underwood LE, Attie KM, Baptista J. Genentech Collaborative Study Group. Growth hormone $(\mathrm{GH})$ dose-response in young adults with childhood-onset GH deficiency: a two-year, multicenter, multiple-dose, placebo-controlled study. J Clin Endocrinol Metab (2003) 88(11):5273-80. doi: 10.1210/jc.2003030204

25. Shalet SM, Shavrikova E, Cromer M, Child CJ, Keller E, Zapletalová J, et al. Effect of growth hormone (GH) treatment on bone in postpubertal GHdeficient patients: a 2-year randomized, controlled, dose-ranging study. J Clin Endocrinol Metab (2003) 88(9):4124-9. doi: 10.1210/jc.2003-030126

26. Mauras N, Pescovitz OH, Allada V, Messig M, Wajnrajch MP, Lippe B. Transition Study Group. Limited efficacy of growth hormone (GH) during transition of GH-deficient patients from adolescence to adulthood: a phase III multicenter, double-blind, randomized two-year trial. J Clin Endocrinol Metab (2005) 90(7):3946-55. doi: 10.1210/jc.2003-030126

27. Boot AM, van der Sluis IM, Krenning EP, de Muinck Keizer-Schrama SM. Bone mineral density and body composition in adolescents with childhood- 
onset growth hormone deficiency. Horm Res (2009) 71(6):364-71. doi: $10.1159 / 000223422$

28. Hyldstrup L, Conway GS, Racz K, Keller A, Chanson P, Zacharin M, et al. Growth hormone effects on cortical bone dimensions in young adults with childhood-onset growth hormone deficiency. Osteoporos Int (2012) 23 (8):2219-26. doi: 10.1007/s00198-011-1854-0

29. Modesto Mde J, Amer NM, Erichsen O, Hernandez S, dos Santos CD, de Carvalho JÂ, et al. Muscle strength and body composition during the transition phase in patients treated with recombinant GH to final height. $J$ Pediatr Endocrinol Metab (2014) 27(9-10):813-20. doi: 10.1515/jpem-20130317

30. Baroncelli GI, Bertelloni S, Sodini F, Saggese G. Acquisition of bone mass in normal individuals and in patients with growth hormone deficiency. J Pediatr Endocrinol Metab (2003) Suppl 2:327-35.

31. Bouillon R, Prodonova A. Growth and hormone deficiency and peak bone mass. J Pediatr Endocrinol Metab (2000) 13 Suppl 6:1327-36. doi: 10.1515/ jpem-2000-s604

32. Murray RD, Adams JE, Shalet SM. A densitometric and morphometric analysis of the skeleton in adults with varying degrees of growth hormone deficiency. J Clin Endocrinol Metab (2006) 91(2):432-8. doi: 10.1210/jc.20050897

33. Bouillon R, Koledova E, Bezlepkina O, Nijs J, Shavrikhova E, Nagaeva E, et al. Bone status and fracture prevalence in Russian adults with childhood-onset growth hormone deficiency. J Clin Endocrinol Metab (2004) 89(10):4993-8. doi: 10.1210/jc.2004-0054

34. Abs R, Mattsson AF, Bengtsson BA, Feldt-Rasmussen U, Góth MI, Koltowska-Häggström M, et al. KIMS Study Group. Isolated growth hormone $(\mathrm{GH})$ deficiency in adult patients: baseline clinical characteristics and responses to GH replacement in comparison with hypopituitary patients. A sub-analysis of the KIMS database. Growth Horm IGF Res (2005) 15 (5):349-59. doi: 10.1016/j.ghir.2005.06.018

35. Fideleff HL, Boquete HR, Stalldecker G, Giaccio AV, Sobrado PG. Comparative results of a 4-year study on cardiovascular parameters, lipid metabolism, body composition and bone mass between untreated and treated adult growth hormone deficient patients. Growth Horm IGF Res (2008) 18 (4):318-24. doi: 10.1016/j.ghir.2008.01.002

36. Balercia G, Giovannini L, Paggi F, Spaziani M, Tahani N, Boscaro M, et al. Growth hormone deficiency in the transition period: body composition and gonad function. J Endocrinol Invest (2011) 34(9):709-15. doi: 10.3275/7804

37. Götherström G, Bengtsson BA, Bosaeus I, Johannsson G. Svensson J. A 10year prospective study of the metabolic effects of growth hormone replacement in adults. J Clin Endocrinol Metab (2007) 92:1442-5. doi: 10.1210/jc.2006-1487

38. Fideleff HL, Jonsson B, Koltowska-Häggström M, Boguszewski MC, Wilton P, Boquete HR. GH deficiency during the transition period: clinical characteristics before and after GH replacement therapy in two different subgroups of patients. J Pediatr Endocrinol Metab (2012) 25(1-2):97-105. doi: 10.1515/jpem.2011.349

39. Johannsson G, Albertsson-Wikland K, Bengtsson BA. Discontinuation of growth hormone $(\mathrm{GH})$ treatment: metabolic effects in GH-deficient and GHsufficient adolescent patients compared with control subjects. Swedish Study Group for Growth Hormone Treatment in Children. J Clin Endocrinol Metab (1999) 84(12):4516-24. doi: 10.1210/jcem.84.12.6176

40. Vahl N, Juul A, Jørgensen JO, Orskov H, Skakkebaek NE, Christiansen JS. Continuation of growth hormone (GH) replacement in GH-deficient patients during transition from childhood to adulthood: a two-year placebo-controlled study. J Clin Endocrinol Metab (2000) 85(5):1874-81. doi: 10.1210/ jcem.85.5.6598

41. Attanasio AF, Shavrikova E, Blum WF, Cromer M, Child CJ, Paskova M, et al. Hypopituitary Developmental Outcome Study Group. Continued growth hormone $(\mathrm{GH})$ treatment after final height is necessary to complete somatic development in childhood-onset GH-deficient patients. J Clin Endocrinol Metab (2004) 89(10):4857-62. doi: 10.1210/jc.2004-0551

42. Bechtold S, Bachmann S, Putzker S, Dalla Pozza R, Schwarz HP. Early changes in body composition after cessation of growth hormone therapy in childhoodonset growth hormone deficiency. J Clin Densitom (2011) 14(4):471-7. doi: $10.1016 /$ j.jocd.2011.05.001
43. Baroncelli GI, Bertelloni S, Sodini F, Saggese G. Longitudinal changes of lumbar bone mineral density (BMD) in patients with GH deficiency after discontinuation of treatment at final height; timing and peak values for lumbar BMD. Clin Endocrinol (Oxf) (2004) 60(2):175-84. doi: 10.1046/ j.1365-2265.2003.01949.x

44. Amer NM, Modesto MJ, Dos Santos CD, Erichsen O, Mascarenhas LPG, NesiFrança S, et al. Resistance exercise alone improves muscle strength in growth hormone deficient males in the transition phase. J Pediatr Endocrinol Metab (2018) 31(8):887-94. doi: 10.1515/jpem-2017-0369

45. Smitka K, Nedvidkova J, Vondra K, Hill M, Papezova H, Hainer V. Acipimox Administration With Exercise Induces a Co-feedback Action of the GH, PP, and PYY on Ghrelin Associated With a Reduction of Peripheral Lipolysis in Bulimic and Healthy-Weight Czech Women: A Randomized Study. Front Endocrinol (Lausanne) (2019) 10:108:108. doi: 10.3389/fendo.2019.00108

46. Roemmler J, Kuenkler M, Otto B, Arafat AM, Bidlingmaier M, Schopohl J. Influence of long-term growth hormone replacement on leptin and ghrelin in GH deficiency before and after glucose load. Regul Pept (2009) 158(1-3):40-6. doi: 10.1016/j.regpep.2009.07.001

47. Yackobovitch-Gavan M, Gat-Yablonski G, Shtaif B, Hadani S, Abargil S, Phillip M, et al. Growth hormone therapy in children with idiopathic short stature - the effect on appetite and appetite-regulating hormones: a pilot study. Endocr Res (2019) 44(1-2):16-26. doi: 10.1080/07435800.2018.1493598

48. Capalbo D, Esposito A, Di Mase R, Barbieri F, Parenti G, Vajro P, et al. Update on early cardiovascular and metabolic risk factors in children and adolescents affected with growth hormone deficiency. Minerva Endocrinol (2012) 37 (4):379-89.

49. Kołtowska-Häggström M, Geffner ME, Jönsson P, Monson JP, Abs R, Hána V, et al. Discontinuation of growth hormone (GH) treatment during the transition phase is an important factor determining the phenotype of young adults with nonidiopathic childhood-onset GH deficiency. J Clin Endocrinol Metab (2010) 95(6):2646-54. doi: 10.1210/jc.2009-2013

50. Lanes R, Paoli M, Carrillo E, Villaroel O, Palacios A. Peripheral inflammatory and fibrinolytic markers in adolescents with growth hormone deficiency: relation to postprandial dyslipidemia. J Pediatr (2004) 145(5):657-61. doi: $10.1016 /$ j.jpeds.2004.07.037

51. Trepp R, Stettler C, Diem P, Christ ER. Effect of growth hormone (GH) on fasting and postprandial metabolism in GH deficiency. Exp Clin Endocrinol Diabetes (2010) 118(9):596-601. doi: 10.1055/s-0029-1243605

52. Ahmid M, Ahmed SF, Shaikh MG. Childhood-onset growth hormone deficiency and the transition to adulthood: current perspective. Ther Clin Risk Manage (2018) 23 14:2283-91. doi: 10.2147/TCRM.S136576

53. Colao A, Di Somma C, Rota F, Di Maio S, Salerno M, Klain A, et al. Common carotid intima-media thickness in growth hormone $(\mathrm{GH})$-deficient adolescents: a prospective study after GH withdrawal and restarting GH replacement. J Clin Endocrinol Metab (2005) 90(5):2659-65. doi: 10.2147/ TCRM.S136576

54. Maison P, Griffin S, Nicoue-Beglah M, Haddad N, Balkau B, Chanson P. Metaanalysis of Blinded, Randomized, Placebo-Controlled Trials. Impact of growth hormone $(\mathrm{GH})$ treatment on cardiovascular risk factors in $\mathrm{GH}$ deficient adults: a Metaanalysis of Blinded, Randomized, Placebo-Controlled Trials. J Clin Endocrinol Metab (2004) 89(5):2192-9. doi: 10.1210/jc.2003030840

55. Hayes FJ, Fiad TM, McKenna TJ. Gender difference in the response of growth hormone (GH)-deficient adults to GH therapy. Metabolism (1999) 48(3):30813. doi: 10.1016/s0026-0495(99)90077-x

56. Feinberg MS, Scheinowitz M, Laron Z. Cardiac dimension and function in patients with childhood onset growth hormone deficiency, before and after growth hormone retreatment in adult age. Am Heart J (2003) 145(3):549-53. doi: $10.1067 / \mathrm{mhj} .2003 .175$

57. Murata M, Kaji H, Mizuno I, Sakurai T, Lida K, Okimura Y, et al. A study of carotid intima-media thickness in GH-deficient Japanese adults during onset among adults and children. Eur J Endocrinol (2003) 148(3):333-8. doi: $10.1530 /$ eje. 0.1480333

58. Lanes R, Gunczler P, Lopez E, Esaa S, Villaroel O, Revel-Chion R. Cardiac mass and function, carotid artery intima-media thickness, and lipoprotein levels in growth hormone-deficient adolescents. J Clin Endocrinol Metab (2001) 86(3):1061-5. doi: 10.1210/jcem.86.3.7268 
59. Oliveira JL, Aguiar-Oliveira MH, D’Oliveira AJr, Pereira RM, Oliveira CR, Farias CT, et al. Congenital growth hormone (GH) deficiency and atherosclerosis: effects of GH replacement in GH-naive adults. J Clin Endocrinol Metab (2007) 92(12):4664-70. doi: 10.1210/jc.2007-1636

60. Lanes R, Soros A, Flores K, Gunczler P, Carrillo E, Bandel J. Endothelial function, carotid artery intima-media thickness, epicardial adipose tissue, and left ventricular mass and function in growth hormone-deficient adolescents: apparent effects of growth hormone treatment on these parameters. J Clin Endocrinol Metab (2005) 90(7):3978-82. doi: 10.1210/jc.2005-0091

61. Capaldo B, Guardasole V, Pardo F, Matarazzo M, Di Rella F, Numis F, et al. Abnormal vascular reactivity in growth hormone deficiency. Circulation (2001) 103(4):520-4. doi: 10.1161/01.cir.103.4.520

62. Zhang S, Li Z, Lv Y, Sun L, Xiao X, Gang X, et al. ardiovascular effects of growth hormone $(\mathrm{GH})$ treatment on $\mathrm{GH}$-deficient adults: a meta-analysis update. Pituitary (2020) 23(4):467-75. doi: 10.1007/s11102-020-01036-0

63. Salomon F, Cuneo RC, Hesp R, Sönksen PH. The effects of treatment with recombinant human growth hormone on body composition and metabolism in adults with growth hormone deficiency. N Engl J Med (1989) 321(26):1797803. doi: 10.1056/NEJM198912283212605

64. Tenuta M, Carlomagno F, Cangiano B, Kanakis G, Pozza C, Sbardella E, et al. Somatotropic-Testicular Axis: A crosstalk between GH/IGF-I and gonadal hormones during development, transition, and adult age. Andrology (2020) 9 (1):168-84. doi: 10.1111/andr.12918

65. Radicioni A, Paris E, Dondero F, Bonifacio V, Isidori A. Recombinant-growth hormone (rec-hGH) therapy in infertile men with idiopathic oligozoospermia. Acta Eur Fertil (1994) 25(5):311-7.

66. Radicioni AF, Paris E, De Marco E, Anzuini A, Gandini L, Lenzi A. Testicular function in boys previously treated with recombinant-human growth hormone for non-growth hormone-deficient short stature. J Endocrinol Invest (2007) 30(11):931-6. doi: 10.1007/BF03349240

67. Devesa J, Caicedo D. The Role of Growth Hormone on Ovarian Functioning and Ovarian Angiogenesis. Front Endocrinol (Lausanne) (2019) 16 10:450:450. doi: 10.3389/fendo.2019.00450

68. Attanasio AF, Shavrikova EP, Blum WF, Shalet SM. Quality of life in childhood onset growth hormone-deficient patients in the transition phase from childhood to adulthood. J Clin Endocrinol Metab (2005) 90(8):4525-9. doi: 10.1210/jc.2005-0439

69. Wirén L, Johannsson G, Bengtsson BA. A prospective investigation of quality of life and psychological well-being after the discontinuation of GH treatment in adolescent patients who had GH deficiency during childhood. J Clin Endocrinol Metab (2001) 86(8):3494-8. doi: 10.1210/jcem.86.8.7709

70. Van Nieuwpoort IC, Drent ML. Cognition in the adult with childhood-onset GH deficiency. Eur J Endocrinol (2008) 159 Suppl 1:S53-7. doi: 10.1530/EJE08-0279

71. Stouthart PJ, Deijen JB, Roffel M, Delemarre-van de Waal HA. Quality of life of growth hormone $(\mathrm{GH})$ deficient young adults during discontinuation and restart of GH therapy. Psychoneuroendocrinology (2003) 28(5):612-26. doi: 10.1016/s0306-4530(02)00045-8

72. Nguyen VT, Misra M. Transitioning of children with GH deficiency to adult dosing: changes in body composition. Pituitary (2009) 12(2):125-35. doi: 10.1007/s11102-008-0101-y

73. Geffner ME. Growth hormone replacement therapy: transition from adolescence to adulthood. J Clin Res Pediatr Endocrinol (2009) 1(5):205-8. doi: 10.4274 /jcrpe.v1i5.205

74. Birzniece V, Ho KKY. Sex steroids and the GH axis: Implications for the management of hypopituitarism. Best Pract Res Clin Endocrinol Metab (2017) 31(1):59-69. doi: 10.1016/j.beem.2017.03.003

75. Giavoli C, Porretti S, Ferrante E, Cappiello V, Ronchi CL, Travaglini P, et al. Recombinant hGH replacement therapy and the hypothalamus-pituitarythyroid axis in children with GH deficiency: when should we be concerned about the occurrence of central hypothyroidism? Clin Endocrinol (Oxf) (2003) 59(6):806-10. doi: 10.1046/j.1365-2265.2003.01892.x

76. Giavoli C, Bergamaschi S, Ferrante E, Ronchi CL, Lania AG, Rusconi R, et al. Effect of growth hormone deficiency and recombinant hGH (rhGH) replacement on the hypothalamic-pituitary-adrenal axis in children with idiopathic isolated GH deficiency. Clin Endocrinol (Oxf) (2008) 68(2):24751. doi: 10.1111/j.1365-2265.2007.03029.x

77. Sklar CA, Mertens AC, Mitby P, Occhiogrosso G, Qin J, Heller G, et al. Risk of disease recurrence and second neoplasms in survivors of childhood cancer treated with growth hormone: a report from the Childhood Cancer Survivor Study. J Clin Endocrinol Metab (2002) 87(7):3136-41. doi: 10.1210/ jcem.87.7.8606

78. Swerdlow AJ, Reddingius RE, Higgins CD, Spoudeas HA, Phipps K, Qiao Z, et al. Growth hormone treatment of children with brain tumors and risk of tumor recurrence. J Clin Endocrinol Metab (2000) 85(12):4444-9. doi: $10.1210 /$ jcem.85.12.7044

79. Mackenzie S, Craven T, Gattamaneni HR, Swindell R, Shalet SM, Brabant G. Long-term safety of growth hormone replacement after CNS irradiation. $J$ Clin Endocrinol Metab (2011) 96(9):2756-61. doi: 10.1210/jc.2011-0112.

80. Patterson BC, Chen Y, Sklar CA, Neglia J, Yasui Y, Mertens A, et al. Growth hormone exposure as a risk factor for the development of subsequent neoplasms of the central nervous system: a report from the childhood cancer survivor study. J Clin Endocrinol Metab (2014) 99(6):2030-7. doi: $10.1210 / j c .2013-4159$

81. Brignardello E, Felicetti F, Castiglione A, Fortunati N, Matarazzo P, Biasin E, et al. GH replacement therapy and second neoplasms in adult survivors of childhood cancer: a retrospective study from a single institution. J Endocrinol Invest (2015) 38(2):171-6. doi: 10.1007/s40618-014-0179-1.

82. Corrias A, Picco P, Einaudi S, De Sanctis L, Besenzon L, Garrè ML, et al. Growth hormone treatment in irradiated children with brain tumors. J Pediatr Endocrinol Metab (1997) 10(1):41-9. doi: 10.1515/jpem.1997.10.1.41

83. Vassilopoulou-Sellin, Klein MJ, Moore BD3, Reid HL, Ater J, Zietz HA. Efficacy of growth hormone replacement therapy in children with organic growth hormone deficiency after cranial irradiation. Horm Res (1995) 43 (5):188-93. doi: 10.1159/000184276

84. Moshang TJr, Rundle AC, Graves DA, Nickas J, Johanson A, Meadows A. Brain tumor recurrence in children treated with growth hormone: the National Cooperative Growth Study experience. J Pediatr (1996) 128(5 Pt 2):S4-7. doi: 10.1016/s0022-3476(96)70002-1

85. Olsson DS, Buchfelder M, Wiendieck K, Kremenevskaja N, Bengtsson BÅ, Jakobsson KE, et al. Tumour recurrence and enlargement in patients with craniopharyngioma with and without GH replacement therapy during more than 10 years of follow-up. Eur J Endocrinol (2012) 166(6):1061-8. doi: 10.1530/EJE-12-0077

86. Karavitaki N, Warner JT, Marland A, Shine B, Ryan F, Arnold J, et al. GH replacement does not increase the risk of recurrence in patients with craniopharyngioma. Clin Endocrinol (Oxf) (2006) 64(5):556-60. doi: 10.1111/j.1365-2265.2006.02508.x

87. Tamhane S, Sfeir JG, Kittah NEN, Jasim S, Chemaitilly W, Cohen LE, et al. GH Therapy in Childhood Cancer Survivors: A Systematic Review and Meta-Analysis. J Clin Endocrinol Metab (2018) 103(8):2794-801. doi: 10.1210/jc.2018-01205

88. Woodmansee WW, Zimmermann AG, Child CJ, Rong Q, Erfurth EM, BeckPeccoz P, et al. Incidence of second neoplasm in childhood cancer survivors treated with GH: an analysis of GeNeSIS and HypoCCS. Eur J Endocrinol (2013) 168(4):565-73. doi: 10.1530/EJE-12-0967

89. Sbardella E, Crocco M, Feola T, Papa F, Puliani G, Gianfrilli D, et al. GH deficiency in cancer survivors in the transition age: diagnosis and therapy. Pituitary (2020) 23(4):432-56. doi: 10.1007/s11102-020-01052-0

Conflict of Interest: The authors declare that the research was conducted in the absence of any commercial or financial relationships that could be construed as a potential conflict of interest.

Copyright (๑ 2021 Spaziani, Tarantino, Tahani, Gianfrilli, Sbardella, Isidori, Lenzi and Radicioni. This is an open-access article distributed under the terms of the Creative Commons Attribution License (CC BY). The use, distribution or reproduction in other forums is permitted, provided the original author(s) and the copyright owner(s) are credited and that the original publication in this journal is cited, in accordance with accepted academic practice. No use, distribution or reproduction is permitted which does not comply with these terms. 